\title{
Economic evaluation of a $100 \%$ smoke-free law on the hospitality industry in an Argentinean province
}

\author{
Carlos Candioti, MD, (1) Gustavo Rossini, PhD,(2) Edith Depetris de Guiguet, PhD, (2) \\ Oscar Costa, CPA, ${ }^{(2)}$ Verónica Schoj, MD.(2,3)
}

\section{Candioti C, Rossini G, Depetris de Guiguet E, Costa O, Schoj V. Economic evaluation of a $100 \%$ smoke-free law on the hospitality industry in an Argentinean province. Salud Publica Mex 20 I; 54:225-232.}

\begin{abstract}
Objectives. To assess the economic impact of a $100 \%$ smoke-free law on bars and restaurants in an Argentinean province. Materials and methods. We conducted a time series analysis of restaurant and bar revenues in the province of Santa Fe 31 months before and 29 months after the implementation of the $100 \%$ smokefree environment law. The neighboring province of Entre Rios without smoking restrictions at the time of this study, was used as the control province. Results. Average taxable revenues post-legislation in the province of Santa Fe as a whole and in the two most important cities were higher when compared to the total provincial revenue pre-legislation. No significant differences were observed with the total revenue from the province of Entre Rios. Conclusions. We found no statistically significant evidence that the $100 \%$ smoke-free environment legislation in the province of Santa Fe, Argentina, had a negative impact on the revenues of local bars and restaurants.
\end{abstract}

Keywords: economics; public policy; tobacco smoke pollution
Candioti C, Rossini G, Depetris de Guiguet E, Costa O, Schoj V. Evaluación económica sobre las ventas del sector gastronómico después de una ley de ambientes $100 \%$ libres de humo en una provincia argentina. Salud Publica Mex 20I 2;54:225-232.

\section{Resumen}

Objetivos. Evaluar el impacto económico de una ley de ambientes $100 \%$ libres de humo de tabaco sobre las ventas de bares y restaurantes en una provincia argentina. Material y métodos. Se realizó un análisis de serie temporal sobre las ventas de bares y restaurantes en Santa Fe, 31 meses antes y 29 meses después de la ley. Se utilizó a la provincia vecina de Entre Ríos, sin ley en el momento del estudio, como provincia control. Resultados. El promedio de ventas post-ley tanto en la provincia de Santa Fe como en sus dos ciudades más importantes fue mayor al compararse con el promedio provincial total pre-ley. No se observaron diferencias significativas en las ventas totales al ser comparadas con la provincia de Entre Ríos. Conclusiones. No se demostró evidencia estadísticamente significativa sobre el impacto negativo de la legislación de ambientes 100\% libres de humo sobre las ventas de bares y restaurantes en la provincia de Santa Fe.

Palabras clave: economía; políticas públicas; contaminación por humo de tabaco

(I) Aliar Argentina (SmokeFree Alliance of Argentina). Argentina

(2) Universidad del Litoral. Santa Fe, Argentina.

(3) Fundación InterAmericana del Corazón. Argentina.

Received on: November 10, 2011 • Accepted on: March 12, 2012

Corresponding author: Verónica Schoj. Fundación InterAmericana del Corazón Argentina. Scalabrini Ortiz $24704 \mathrm{H}$ - CABA I 425 - Argentina.

E-mail: veronica.schoj@ficargentina.org 
$\mathrm{T}$ he Framework Convention on Tobacco Control (FCTC) is the world's first international public health treaty adopted by the World Health Assembly. Article 8 addresses second hand-smoke exposure (SHS) as a health risk and identifies interventions to reduce such exposure. ${ }^{1}$ The FCTC calls for ratifying parties to implement clean indoor air laws to protect citizens from SHS. Argentina signed the treaty but as of March 2012 has still not ratified this treaty. ${ }^{2}$ In June 2011, Argentina enacted a tobacco control national law. ${ }^{3}$ However, before the introduction of this law, tobacco control initiatives were undertaken at the local level including provinces and cities.

Santa Fe was the first province to introduce comprehensive smoking prevention and tobacco control legislation. ${ }^{4,5}$ The $100 \%$ smoke-free law was fully enforced and implemented by the end of August, 2006. The main provisions of the legislation included the implementation of $100 \%$ smoke-free environments, the complete ban on tobacco advertising, promotion and sponsorship within the province, and the organization of education campaigns. Evidence of high compliance in the province has been shown in different local studies. A survey conducted simultaneously to this economic study to bar and restaurant owners in 473 venues from the two most important cities of the province of Santa $\mathrm{Fe}$, showed that $98.8 \%$ in Rosario and $93.7 \%$ in Santa Fe reported having implemented 100\% smokefree environments in their own venues. At the moment of the conduction of this survey we observed people smoking in $2.3 \%$ venues from Rosario and $4.1 \%$ venues from the city of Santa Fe. This study which also includes other relevant compliance and perception variables from bar and restaurant owners will be published as a separate article. Also, a locally conducted air quality study performed in 2007 that evaluated suspended air particles using the Sidepak monitor showed that from 56 venues in the cities of Rosario and Santa Fe had average PM levels of 49.79 which are within the expected air quality EPA standards. ${ }^{6}$ In the observation included in this air quality monitoring study we found people smoking in only three venues observed after the implementation of the law. ${ }^{4,7}$

As it has been widely shown, the tobacco industry and its "front groups" have always claimed that smokefree legislation would result in severe economic losses in the "5 B's" group: bars, bowling alleys, billiard halls, betting establishments and bingo halls. ${ }^{8}$ However, most studies conducted worldwide have demonstrated that $100 \%$ smoke-free environments do not have a negative impact on these revenues. ${ }^{9-12}$

The objective of our study was to assess the long term economic impact of the $100 \%$ smoke-free legislation on bar and restaurant revenues in the province of Santa Fe, Argentina.

\section{Materials and methods}

\section{Study design}

We conducted a time series analysis of restaurant and bar revenues in the province of Santa Fe from 31 months before and 29 months after the implementation of the new legislation. We also performed a taxable revenue comparison with the province of Entre Rios. Entre Rios was a good control province for the province of Santa Fe because it is a neighboring province with similar weather, cultural, ethnic and geographic conditions. Although the population size is different (Santa Fe has 3200736 and Entre Rios 1236300 inhabitants) ${ }^{13}$ both provinces are largely urban $(89.2 \%$ of the population from Santa Fe and $82.5 \%$ of the population from Entre Rios live in cities and towns). ${ }^{14}$ Also, according to the National Survey of Risk Factors conducted in 2005, smoking prevalence is also similar in both provinces: $31.8 \%$ of the population between 14 and 64 years of age smoke in Santa Fe vs. 31.7\% in Entre Rios. ${ }^{15}$ Furthermore, the annual growth rate for the gross state product (GSP) for the 2002-2006 period was 7.7\% for Santa Fe and 7.0\% for Entre Rios. The main economic activities in both provinces are agriculture, farming and other business and manufacturing activities. The share of the bars, restaurants and hotels in the GDP of both provinces is similarly low with an average of $0.79 \%$ in Santa Fe and $1.56 \%$ Entre Rios for bars, restaurants and hotels for the 1993-2008 period. ${ }^{16-18}$

Taxable revenues are defined as the amount declared by bars and restaurants to the Provincial Revenue Service. This value was then divided by the total number of venues in order to obtain average revenue. The result of this division was used in the data analysis. To assess methodological quality of our study we used Siegel's criteria. ${ }^{19}$

\section{Data collection}

We included monthly taxable revenues from bars and restaurants obtained from the Department of Statistics and Technical Studies of the Provincial Revenue Service (API) for the province of Santa Fe and the General Revenue Office (DGR) for the province of Entre Rios. Data obtained from API included data from the city of Rosario, the city of Santa Fe and the total provincial taxable revenue. The city of Santa Fe is the capital city of the province of Santa Fe (about 400000 inhabitants) and Rosario is the most populated city with 1198528 
inhabitants, both cities covering $49.87 \%$ of the total provincial population. ${ }^{13}$ Monthly taxable revenue listings were obtained from a section within API's Business Activity Code that included all Food and Beverage Retail Services. These services are included in item $\mathrm{H}$, "Hotel and Restaurant Services", of the same code. Within this item the following services are included: a) sale of food and beverages in restaurants and clubs (code 552111), b) sale of food and beverages in bars, coffee shops, and pizzerias (code 552112), c) beverage sale (code 552113), d) food and beverage sale at milk bars (code 552114), e) food and beverage sale at patisseries and similar venues without shows (code 552115), f) food and beverages sales at teashops (code 552116), g) food and beverage sale at venues that sale food and beverages (code 552119), h) icecream sale (code 552120), i) catering services (code 552210), and j) elaboration and sale of takeout food (code 552290). Data from the DGR only included the total provincial revenue. Data provided by both agencies included monthly taxable revenue listings from January 2003 to December 2007.

\section{Data analysis}

For the objective outcome measure, we used two methodological approaches: multiple regression model and intervention analysis. Both methods are used to examine the effect of smoke-free legislation on average bar and restaurant revenues and to compare the consistency of the results.

\section{Regression analysis}

Four regressions were estimated. The first three use the value of taxable revenues as the dependent variable. If the new legislation negatively affected bar and restaurant businesses, revenues would be expected to decline as soon as the new legislation entered into force. In the second regression model, we used a ratio only for bar and restaurant revenues for the provinces of Santa Fe and Entre Rios. Again, if the legislation adversely affected bar and restaurant sales, this ratio would be expected to fall.

The following independent variables were considered: 1 ) average wages (S); 2) seasonal variation (E);3) gas consumption in Santa Fe (G); 4) 100\% smokefree environment law (L). The wage variable is used to analyze the effect of the economic activity on taxable revenues. The inclusion of monthly binary variables has been tested to model the effect of seasonal factors but many of them are not statistically significant. Thus, we have included quarterly binary variables. Winter includes June, July and August; Spring includes Sep- tember, October and November. Summer includes December, January and February and Fall includes March, April and May. The variable corresponding to the consumption of gas makes it possible to include the economic changes that are not considered in the wage variable. Last, a binary variable includes the periods that allow for the quantification of the effect of the law on the taxable revenues of bars and restaurants. Average bar and restaurant revenues and wages were adjusted for inflation using the consumer price index published by the Statistical Institute of Santa Fe. The estimated regression model was as follows:

$$
\log (I)=\beta_{0}+\beta_{1} L+\beta_{2} \log (S)+\sum \beta_{i} E_{i}+\beta \log (G)+\mu
$$

Where I is the value of the monthly taxable revenues for all bars and restaurants from the three datasets (city of Santa Fe, city of Rosario and Province of Santa Fe) or the ratio of the monthly taxable revenues in Santa Fe versus the monthly sales in Entre Rios. Taxable revenues, wages and gas consumption are expressed in logarithmic form. $\mathrm{B}_{0}$ to $\mathrm{B}_{6}$ are parameters of the equation to be estimated.

The Breusch-Pagan test for heteroskedasticity and the Durbin-Watson test for autocorrelation were used to evaluate the suitability of the model.

\section{Intervention analysis}

The Intervention Analysis was also used to determine the impact of the $100 \%$ smoke-free legislation on bar and restaurant taxable revenues. The AutoRegressive Moving Average Model (ARMA) may be expressed as follows:

$$
I_{t}=\mathrm{b}_{0}+A(L) I_{t-1}+\mathrm{c}_{0} \mathrm{z}_{\mathrm{t}}+B(L) \varepsilon_{t}
$$

Where I is the value of the monthly taxable revenues for all bars and restaurants, $A(L)$ and $B(L)$ are polynomials, $L$ is the "lag" operator and $z$ the intervention variable (binary). In our study, the value of the intervention variable changes from 0 to 1 which is commonly referred to as "pure jump" process.

The initial or immediate effect of the new legislation is shown by the magnitude of the $c_{0}$ coefficient. Statistical significance was assessed with a standard t-test to show whether or not the implementation of the smoke-free environment law had a negative impact on bar and restaurant revenues. Variables were first tested to determine the presence of unit roots. Only in the case of the city of Rosario we could not reject the presence of unit root. Thus, the model was estimated with differences for this city. 


\section{Results}

Monthly taxable revenues in the cities of Santa Fe and Rosario and for the Province of Santa Fe did not decline in the two most important cities and in the province of Santa Fe after the implementation of the $100 \%$ smokefree legislation (table I).

Figure 1 shows bar and restaurant taxable revenues during the study period in the province of Santa Fe. The series shows that taxable rates did not decline after the implementation of the 100\% smoke-free legislation. Although they showed some variations, the linear trend estimation shows a higher value in average bar and restaurant taxable revenues post-legislation.

Table II shows the results of the estimated multiple linear regression models. In regressions 1, 2, and 3 the dependent variable corresponds to taxable revenues per bar and restaurant; in regression 4 the dependent variable is the ratio of the average taxable revenues comparing the province of Santa Fe with the province of Entre Ríos. Independent variables included in the analysis are: Implementation of the law, wages (estimated in Argentinean pesos), seasonal variation and gas consumption.

The variable of most interest shows the effect of the implementation of the smoke-free legislation on the taxable revenues of bars and restaurants. In the first model, results show that the effect of the law in
Table I

Taxable revenues in Argentinean pesos before and AFTER THE IMPLEMENTATION OF THE NEW LEGISLATION Province of Santa Fe, Argentina, 2003-2007

$$
\begin{array}{cc}
\text { Average } & \text { Standard } \\
\text { monthly tax } & \text { error }(\$) \\
\text { revenue (\$) } &
\end{array}
$$

City of Santa Fe

\begin{tabular}{lll} 
Before & 13861 & 2654.7 \\
\hline After & 15355 & 1911.8 \\
\hline Total sales during the study period (2003-2007) & 14583 & 2425.8
\end{tabular}

City of Rosario

\begin{tabular}{lll} 
Before & 13627 & 2091.5 \\
\hline After & 17623 & 1805.9 \\
\hline Total sales during the study period (2003-2007) & 15558 & 2797.6
\end{tabular}

Province of Santa Fe

\begin{tabular}{lll} 
Before & 10477 & | | | 5.5 \\
\hline After & 1224 | & | 02I.8 \\
\hline Total sales during the study period (2003-2007) & I| 329 & | 400.I
\end{tabular}

Figures have been inflation adjusted and are expressed in Argentinean pesos. The dollar/peso exchange rate between January 2003 and December 2007 has changed from 3.25 to 3.13 pesos/dollar. Average rate was 2.99 pesos/dollar

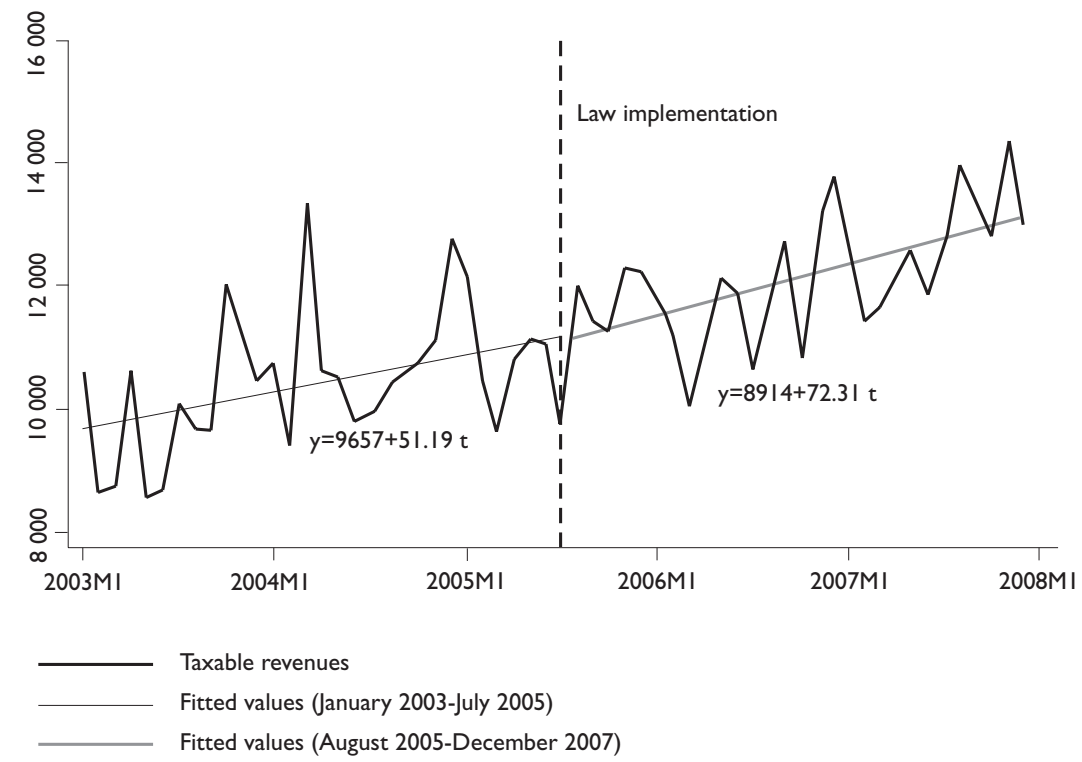

Figure I. Pre-and post-monthly bar and restaurant taxable ReVenues in the province of Santa Fe, 2003-2007 
Table II

Results of the Multiple Regression Model on the Taxable Revenues per Venue - Province of Santa Fe and Province of Entre Ríos, Argentina, 2003-2007

\begin{tabular}{|c|c|c|c|c|}
\hline \multirow[b]{2}{*}{ Independent variables } & \multicolumn{4}{|c|}{ Dependent variable } \\
\hline & Province of Santa Fe & City of Santa Fe & City of Rosario & Province of Entre Ríos \\
\hline & (I) & (2) & (3) & (4) \\
\hline \multirow[t]{2}{*}{ Implementation of the law } & -0.0232 & -0.0467 & -0.0084 & 0.0052 \\
\hline & $(0.0369)$ & $(0.0738)$ & $(0.044)$ & $(0.1640)$ \\
\hline \multirow[t]{2}{*}{ Wages (Arg \$/month) } & $0.7498 *$ & $0.6367^{*}$ & $1.222 *$ & $-1.598 *$ \\
\hline & $(0.152)$ & $(0.3038)$ & $(0.1838)$ & $(0.6747)$ \\
\hline \multicolumn{5}{|l|}{ Seasonal variation } \\
\hline \multirow[t]{2}{*}{ Fall } & $-0.0667 *$ & -0.0491 & $-0.0955^{*}$ & .0222 \\
\hline & $(0.0282)$ & $(0.056)$ & $(0.034 I)$ & $(0.1254)$ \\
\hline \multirow[t]{2}{*}{ Winter } & $-0.0588 *$ & -0.1002 & -0.0412 & -.2029 \\
\hline & $(0.0279)$ & $(0.0558)$ & $(0.0337)$ & $(0.124)$ \\
\hline \multirow[t]{2}{*}{ Summer } & $-0.0774 *$ & -0.0797 & $-0.1268^{*}$ & $-.2875^{*}$ \\
\hline & $(0.0282)$ & $(0.0564)$ & $(0.034 I)$ & $(0.1252)$ \\
\hline \multirow[t]{2}{*}{ Gas consumption (m³onth) } & 0.0546 & 0.0872 & -0.0576 & -.0921 \\
\hline & $(0.0928)$ & $(0.1854)$ & $(0.112)$ & $(0.4 I \mid 8)$ \\
\hline \multirow[t]{2}{*}{ Constant } & $3.156 *$ & 3.938 & 1.067 & $15.60 *$ \\
\hline & $(1.209)$ & $(2.4 I 5)$ & $(\mathrm{I} .46 \mathrm{I})$ & $(5.364)$ \\
\hline \multicolumn{5}{|l|}{$\begin{array}{l}\text { Standard Error in parenthesis } \\
* \text { Statistically significant at } 5 \%\end{array}$} \\
\hline
\end{tabular}

the province of Santa Fe is -0.0232 showing a $2.32 \%$ reduction on the taxable revenues. However, this effect is not statistically significant after controlling for other economic and seasonal variables in the model. In the second and third regression model, results from the cities of Santa Fe and Rosario are similar. The effect of the law shows a $4.67 \%$ and $0.84 \%$ reduction with no statistical significance. In the case of the regression model using a ratio as dependent variable where we compared bar and restaurant taxable revenues in one province (Santa Fe) with legislation versus one province (Entre Ríos) without legislation, results show a $0.52 \%$ positive effect in Santa Fe post-legislation. However, this result is not a statistically significant difference which indicates that the implementation of the law had no impact on bars and restaurants revenues in Santa Fe as compared with Entre Ríos.

Variables were first tested to determine the presence of unit roots. Only in the case of the city of Rosario we could not reject the presence of unit root (Table III).
Therefore, for the first two series we included an ARMA model for the city of Santa Fe and the province of Santa Fe and an ARIMA model for the city of Rosario. Best-fit models including lagged dependent variables are shown in Table III. In the intervention analysis, the coefficient of the "Implementation of the law" variable shows that the new law had no negative economic impact on bar and restaurant taxable revenues. In fact, some coefficients showed positive results.

For the city of Santa Fe and for the Province of Santa Fe, coefficients showed a positive immediate effect post-legislation. In the province of Santa Fe, there was an increase of $\$ 1804.06$ (Argentinean pesos) postlegislation. In the city of Santa Fe, we also found an average increase of \$1569.98 (Argentinean pesos) during the study period. However, because autoregressive coefficients imply convergence, the long-term effect of the implementation of the smoke-free legislation is null. In the city of Rosario the coefficient of the "Implementation of the Law" variable was not statistically significant. 
Table III

Results of the Intervention Analysis - Province of Santa Fe, Argentina, 2003-2007

\begin{tabular}{|c|c|c|c|}
\hline & $\begin{array}{l}\text { Province of Santa Fe } \\
\text { (Standard Error) }\end{array}$ & $\begin{array}{l}\text { City of Santa Fe } \\
\text { (Standard Error) }\end{array}$ & $\begin{array}{l}\text { City of Rosario } \\
\text { (Standard Error) }\end{array}$ \\
\hline \multirow[t]{2}{*}{ Implementation of the law } & $1804.06^{\ddagger}$ & $1569.98 \S$ & 157.15 \\
\hline & $(427.16)$ & $(770.99)$ & $(0.30)$ \\
\hline \multirow[t]{2}{*}{$\operatorname{AR}(I)$} & $0.357^{\ddagger}$ & & -0.624 \\
\hline & $(0.145)$ & & $(1.34)$ \\
\hline \multirow[t]{2}{*}{$\operatorname{AR}(2)$} & & & -0.295 \\
\hline & & & $(0.14)^{\S}$ \\
\hline \multirow[t]{2}{*}{$\mathrm{MA}(\mathrm{I})$} & & 0.229 & \\
\hline & & $(0.12)^{*}$ & \\
\hline \multirow[t]{2}{*}{ Constant } & 10466.79 & |3826.7| & 63.46 \\
\hline & $(282.06)^{\ddagger}$ & $(503.3 \mathrm{I})^{\S}$ & $(180.56)$ \\
\hline \multirow[t]{2}{*}{$\mathrm{Q}(4)^{\#}$} & 2.23 & 1.08 & 1.09 \\
\hline & $(0.66)$ & $(0.78)$ & $(0.89)$ \\
\hline \multirow[t]{2}{*}{ Wald test ${ }^{\#}$} & 26.75 & 8.94 & 78.79 \\
\hline & $(0.00)$ & $(0.00 I)$ & $(0.00)$ \\
\hline Dickey-Fuller Test ${ }^{\&}$ & 3.72 & 3.82 & 2.85 \\
\hline Phillips-Perron Test ${ }^{*}$ & -3.562 & -5.683 & -2.591 \\
\hline $\begin{array}{l}\text { * Standard Errors in parent } \\
\text { \# Statistically significant at I } \\
\text { \& Statistically significant at } 5 \\
\text { \# P-value in parenthesis AR( } \\
\& 5 \% \text { Critical Value }=2.924 \\
\text { * } 5 \% \text { Critical Value }=-2.924\end{array}$ & Term, MA(.) Moving & & \\
\hline
\end{tabular}

\section{Discussion}

Our study shows no evidence of bar and restaurant taxable revenue decline after the implementation of the 100\% smokefree legislation in the Province of Santa Fe and in its two main cities (Rosario and Santa $\mathrm{Fe}$ ). Also, when taxable revenues were compared with the province of Entre Rios, the multivariate regression model adjusted to all the variables did not show statistically significant differences in the taxable revenues of bars and restaurants before and after the law in both provinces.

One of the strengths of our study is that it includes a 60-month time series analysis covering 31 months before and 29 months after the implementation of the law in Santa Fe which is a considerable time to adjust with different measures -seasonal variations, economic growth, and wages thus strengthening our results. Furthermore, our study was performed using an independent data source. However, this study is subject to some limitations. We did not have access to information on revenues for each specific bar and restaurant and we did include individual variables in our analysis. This may not represent the actual situation of each bar and restaurant. Also, data from this study has been useful in the province of Santa Fe but other provinces would have benefited from a local analysis as they have different economic structures. Last, the province of Entre Rios that was used as the comparison group for the province of Santa Fe is not the best comparison group as it has a lower Gross Provincial Product, less population density and different economic activities. 
Our results are consistent with those from other international studies ${ }^{9,12,20, *}$ that followed Siegel's criteria and did not have conflicts of interest with tobacco industry involvement or funding. A recent economic evaluation performed in Mexico city also showed that the implementation of the smokefree law had no negative impact on restaurants' income, employees' wages and levels of employment. ${ }^{21}$

Progress has been achieved in the implementation of 100\% smokefree legislation with the inclusion of bars and restaurants in Latin America and the Caribbean during the last years: Uruguay (2006), Panama (2008), Guatemala (2009), Colombia (2009), Peru (2010), Trinidad \& Tobago (2010), Honduras (2010), Barbados (2010), ${ }^{22}$ and Venezuela (2011). Also, the most populated cities in the region have introduced this type of legislation: Rio de Janeiro and Sao Paolo (Brazil), Mexico City (Mexico), City of Buenos Aires (Argentina). ${ }^{23}$ However, several countries have introduced legislation that allows the implementation of designated smoking areas (DSAs) in the hospitality sector during the time period: Nicaragua (2010), Bolivia (2009), Ecuador (2008), Mexico (2008), Chile (2006). ${ }^{22}$ The main argument to implement DSAs has been the economic losses imposed by this type of legislation to the hospitality sector. This shows that the tobacco industry arguments have remained a powerful rhetoric in tipping the scales in favor of their business. ${ }^{24}$ Thus, our study and the study performed in Mexico City $^{22}$ are crucial to counteract the interference of the tobacco industry in the legislative process of the Latin American and the Caribbean region.

In Argentina, as in other Latin American countries, the myth of profits loss has been a very strong argument of the tobacco industry turning the hospitality sector into its main lobbying group. ${ }^{24}$ Although these arguments have been proved to be ineffective even by the same tobacco industry, ${ }^{25}$ hospitality establishments were the priority for Philip Morris' Courtesy of Choice programme which penetrated in the hospitality sector of the entire region. ${ }^{8}$ Between the years 2004 and 2008 the hospitality sector was the main group to lobby against this 100\% smokefree environment legislation arguing economic losses in their business. These arguments were effective to introduce legislation consistent with the tobacco industry's interests. In October 2005, the city of Buenos Aires and in October 2008 the province of Buenos Aires both introduced legislation that allowed the implementation of DSAs. ${ }^{26-28}$ These cases are among

\footnotetext{
* Ramos A, Curti D. Evaluacion economica del impacto de la medida de $100 \%$ libre de humo de tabaco sobre el sector de la hosteleria en Uruguay: 2003. Documento no publicado.
}

the most significant examples of tobacco industry interference and the success of their arguments.

However, the position of the hospitality sector has been changing in our country. In fact, generating local evidence made it possible to strengthen the relationship of health organizations with the hospitality sector that even in the province of Santa Fe recognized the lack of economic losses after the new law. This study was useful to facilitate the enactment of $100 \%$ smokefree environment legislation in other Argentinean provinces during the last years, including the modification of the law in the city of Buenos Aires which eliminated DSAs ${ }^{23}$ in bars and restaurants, the provinces of Entre Rios (2009), Santiago del Estero (2009), and San Luis (2010). In these provinces bar and restaurant owners were not obstructive but supportive of the new law.

The dissemination of our results and the use of this study as an advocacy tool nationwide have been key factors to promote $100 \%$ smokefree environment legislation and especially to obtain the support of the hospitality sector thus forcing the tobacco industry to look for other allies to hinder tobacco control policies such as retailers and owners of gambling establishments.

\section{Acknowledgements}

We thank Lorena Allemandi, from Fundación InterAmericana del Corazón-Argentina, for the elaboration and Andrew Hyland, PhD from the Roswell Park Cancer Institute, for the review of this manuscript.

Declaration of conflict of interests: The authors declare not to have conflict of interests.

\section{References}

I. World Health Organization. WHO Framework Convention on Tobacco Control (WHO FCTC) 2007. [Accessed 2007 I2 November]. Available at: http//www.who.int/tobacco/framework/en/.

2. Mejia R, Schoj V, Barnoya J, Flores ML, Pérez-Stable EJ. Tobacco industry strategies to obstruct the FCTC in Argentina. CVD Prev Control 2008;3:I73-179.

3. Ley 26.687: Regulación de publicidad, promoción y consumo de los productos elaborados con tabaco. Sancionada: Junio I, 20I I. Promulgada: Junio 13, 201 I. [Accessed 20I I June 14]. Available at: http://www. boletinoficial.gov.ar/DisplayPdf.aspx?s=BPBCF\&f=20 I I06 |4. $20 \mathrm{I}$. 4. Sebrié EM, Glantz SA. Local smoke-free policy development in Santa Fe, Argentina. Tob Control 2010;19:110.

5. Ley de Control de Tabaquismo de Santa Fe No. 12432. [Accessed 201 I I5 Mar]. Available at: http://www.aliarargentina.org/images/ stories/0I_53ley_12432_provincia_de_santafe.pdf. 6. United States Environmental Protection Agency. Air Quality Index. A Guide to Air Quality and Your Health. [Accessed 20II 20 May]. Available at: http://www.enviroflash.info/assets/pdf/AQI_2003_9-3.pdf. 
7. Schoj V, Sebrié EM, Pizarro ME, Hyland A, Travers MJ. Informing effective smokefree policies in Argentina: Air quality monitoring study in 15 cities (2007-2009). Salud Publica Mex 2010;52:SI57-SI67.

8. Sebrié EM, Glantz SA. "Accommodating" smoke-free policies: tobacco industry's Courtesy of Choice programme in Latin America. Tob Control 2007; 16:e6.

9. Eriksen M, Chaloupka F. The economic impact of clean indoor air laws. CA Cancer J Clin 2007;57:367-78.

10. Thomson G, Wilson N. One year of smokefree bars and restaurants in New Zealand: impacts and responses. BMC Public Health 2006; 14:64. II. Stolzenberg L, D'Alessio SJ. Is nonsmoking dangerous to the health of restaurants? The effect of California's indoor smoking ban on restaurant revenues. Evaluation review 2007;31:75.

12. Scollo M, Lal A, Hyland A, Glantz S. Review of the quality of studies on the economic effects of smoke-free policies on the hospitality industry. Tob Control 2003;12:13.

13. Censo Nacional 2010 (National Census 2010). [Accessed 201118

Mar]. Available at: http://www.censo2010.indec.gov.ar/preliminares/ cuadro_santafe.asp.

14. 200I Argentinean National Census. [Accessed 20II I8 May]. Available at: http://www.indec.gov.ar/principal.asp?id_tema=93।4

15. Encuesta Nacional de Factores de Riesgo (National Survey of Risk Factors) [Accessed 20II I8 Mar]. Available at: http://www.msal.gov.ar/ ENT/Publicaciones/PDF/Encuesta\%20Nacional\%20De\%20Factores\%20 De\%20Riesgo\%202005\%20-\%20Version\%20Breve.pdf.

16. Producto Bruto Geografico de las Provincias Argentinas (Gross State Product of the Argentinean Provinces). [Accessed 201120 Mar]. Available at: http://www.santafe.gov.ar/index.php/web/content/ download/78880/38| I 93/version///file/informe_PBG_oct_09.pdf. 17. Producto Bruto Geografico. Provincia de Santa Fe. 1993-2009 Resultados Preliminares. [Accessed 20 II 22 May]. Available at: www. santafe.gov.ar.

18. Producto Bruto Geografico. 1993-2008. Gobierno de Entre Rios. [Accessed 20II 22 May]. Available at: www.entrerios.gov.ar.

19. Siegel M. Economic impact of 100\% smokefree restaurant ordinances. Smoking and restaurants: A guide for policymakers. Berkeley: UC
Berkeley/UCSF Preventive Medicine Residency Program; American Heart Association, California Affiliate; Alameda County Health Care Services Agency; Tobacco Control Program, 1992.

20. Ludbrook A, Bird S, van Teijlingen E. International review of the health and economic impact of the regulation of smoking in public places. Edinburgh: NHS Health Scotland, 2005.

21. Guerrero-López C, Jiménez-Ruiz J, Reynales-Shigematsu L, Waters $\mathrm{H}$. The economic impact of Mexico City's smoke-free law. Tob Control 20I I. doi: I0.I |36/tc.2010.036467 [published online first].

22. Allemandi L, Schoj V, Gutkowski P, Itchart L, Champagne B. Framework Convention on Tobacco Control: Challenges for Latin America and the Caribbean. Civil Society Report. Buenos Aires, Argentina: InterAmerican Heart Foundation, 2010.

23. Ley N. 3718 de Control de Tabaco de la Ciudad Autonoma de Buenos Aires. [Accessed 20II 18 Mar]. Available at: http://www.cedom. gov.ar/es/legislacion/normas/leyes/ley37/8.html.

24. Dearlove J, Bialous $S$, Glantz $S$. Tobacco industry manipulation of the hospitality industry to maintain smoking in public places. Tob Control 2002; I1:94-104

25. Legacy Tobacco Documents Library. University of San Francisco, California [Accessed 20II 29 Mar]. Available at: http://legacy.library.ucsf. edu/tid/vnf77e00/pdf;jsessionid=F847475C4I66EI FEC525BFBB725F065 I.tobacco04.

26. Sebrié E, Schoj V, Glantz S. Smokefree environments in Latin America: on the road to real change? Prev Control 2008;3:2I-35.

27. Ordenanza No. 47670: Fijacion de sectores para fumadores y no fumadores en restaurantes, bares, confiterias y casas de lunch del Gobierno de la Ciudad de Buenos Aires. [Accessed 20II 25 Mar] Available at: http://www.todoelderecho.com/newsearch/search. pl!Realm=legislacion\%20capital\&Match=|\&Terms=legislacion\&maxhits=| O\&Rank $=245 \mathrm{I}$.

28. Ley de Control de Tabaco de la Provincia de Buenos Aires $\mathrm{N}^{\circ}$ 13.894. [Accessed 20II 23 Mar]. Available at: http://www.gob.gba.gov.ar/ legislacion/legislacion/l-I3894.html. 